\begin{tabular}{|l|l|l||}
\hline \multicolumn{2}{|c|}{ PublisherInfo } \\
\hline \hline PublisherName & $:$ & BioMed Central \\
\hline \hline PublisherLocation & $:$ & London \\
\hline \hline PublisherImprintName & $:$ & BioMed Central \\
\hline \hline
\end{tabular}

\title{
Immunizing against Alzheimer's
}

\begin{tabular}{|l|l|l||}
\hline \multicolumn{2}{|c|}{ ArticleInfo } \\
\hline \hline ArticleID & $:$ & 3872 \\
\hline \hline ArticleDOI & $:$ & $10.1186 /$ gb-spotlight-20001222-02 \\
\hline \hline ArticleCitationID & $:$ & spotlight-20001222-02 \\
\hline \hline ArticleSequenceNumber & $:$ & 309 \\
\hline \hline ArticleCategory & $:$ & Research news \\
\hline ArticleFirstPage & $:$ & 1 \\
\hline \hline ArticleLastPage & $:$ & 2 \\
\hline \hline & $:$ & RegistrationDate : 2000-12-22 \\
ArticleHistory & $:$ & OnlineDate $\quad$ 2000-12-22 \\
\hline \hline ArticleCopyright & $:$ & BioMed Central Ltd2000 \\
\hline \hline ArticleGrants & $:$ & \\
\hline \hline ArticleContext & $:$ & 130591111 \\
\hline \hline
\end{tabular}


Abnormal processing and deposition of amyloid- $\beta$ peptide $(A \beta)$ in extracellular plaques are thought to be central to the pathogenesis of Alzheimer's disease. Immunization with $A \beta$ reduces the amount of brain amyloid, and now in the 21/28 December Nature, Janus et al. (Nature 2000, 408:979-982) and Morgan et al. (Nature 2000, 408:982-985) report that similar immunization protocols also reduce the learning deficit seen in mouse models of Alzheimer's disease.

Janus et al. immunize at $6,8,12,16$ and 20 weeks with $A \beta$ in $\beta$-pleated sheet conformation, and test using a Morris water maze at 11,15, 19 and 23 weeks. The immunized mice perform significantly better than non-immunized littermates at 11 and 23 weeks, when two discrete increases in amyloid burden are detected in non-immunized mice. Immunization reduces the amount of dense-cored $A \beta$ plaques by approximately $50 \%$, suggesting that the elicited antibodies may inhibit assembly of $A \beta$ fibrils rather than clear all $\mathrm{A} \beta$.

Morgan et al. immunize monthly before assaying at 15.5 months using a radial-arm water maze that tests working memory. (Chen et al., reporting in the same issue of Nature, find that only the performance of tasks that require this sort of working or episodic-like memory are correlated with the age-related increase in plaque burden (Nature 2000, 408:975-979).) At 15.5 months the immunized mice are better than non-immunized mice on the fourth trial, and as good as wild-type mice by the fifth trial. In contrast the mice in the Janus et al. study never improved to reach the performance levels of wildtype mice. Morgan et al., the group not affiliated with a pharmaceutical company, "strongly recommend testing" of $A \beta$ immunization for both treatment and prevention of Alzheimer's disease.

Further links to $\mathrm{A} \beta$ come in the 22 December Science. Ertekin-Taner et al. use plasma $\mathrm{A} \beta 42$ levels as a surrogate for late-onset Alzheimer's disease (LOAD), and come up with a locus on chromosome 10 linked to the disease (Science 2000, 290:2303-2304). Myers et al. confirm this observation using an analysis of affected sibling pairs, and find a significance level that suggests the new locus is as important as the E4 allele of apolipoprotein E, the only known genetic risk factor for LOAD (Science 2000, 290:2304-2305). The new locus is near, but apparently distinct from, the locus identified by Bertram et al. (Science 2000, 290:2302-2303). The latter locus is very near or identical to the gene for insulindegrading enzyme, which may help degrade and clear $\mathrm{A} \beta$.

\section{References}

1. Immunization with amyloid-beta attenuates Alzheimer-disease-like pathology in the PDAPP mouse.

2. Nature, [http://www.nature.com/nature/]

3. Science, [http://www.sciencemag.org/]

4. Effects of age, sex, and ethnicity on the association between apolipoprotein E genotype and Alzheimer disease. A meta-analysis. APOE and Alzheimer Disease Meta Analysis Consortium.

5. Exploring the etiology of Alzheimer disease using molecular genetics. 